\title{
Transformation of Security and Intelligence Services in Latvia
}

\section{Andis Kudors}

Department of Political Science, University of Latvia, https://www.rsu.Iv/

\begin{abstract}
The article examines in detail the process of setting up the security services of Latvia in the period prior to and after gaining full independence with the dissolution of the Soviet Union. The author emphasizes that a successful transition towards a consolidated democracy requires decisive and quick actions in selecting personnel with intelligence experience under the totalitarian regime, yet loyal to the national ideals and the principles of democracy, the need for a clear legislative framework, and comprehensive democratic control of the services along parliamentary, government, judicial, prosecution, and financing venues.
\end{abstract}

Keywords: intelligence, counter-intelligence, post-communist transition, checks and balances, Latvia, Russia.

\section{Introduction}

Latvia had lost its statehood de facto in the years of the Soviet occupation. Its security structures during the Soviet period were established by an external, hostile force. Therefore, we cannot talk about the 'transformation' of Latvian security services in 1990 and 1991, but rather about 'demolition' and 'rebuilding anew.'

However, the history of Latvian security services did not start in 1991. The need to create special services appeared with the proclamation of the independence of the Republic of Latvia on November 18, 1918. On July 29, 1919, the Security Department of the Ministry of the Interior was established, whose task was to combat crimes against the constitutional order. The Political Guard of the Ministry of the Interior was created on October 2, 1920, while from May 1924 to June 1939, the functions of the counter-intelligence and internal security service were performed by the Political Bureau of the Ministry. After the occupation by 
the Soviet Union in 1940, more than 90 percent of Latvian special service officers were killed or died in Soviet prisons. ${ }^{1}$

Until the establishment of the USSR Committee for State Security (KGB) in 1954, many Soviet security authorities operated in occupied Latvia from 1940 (with a break during the German occupation in 1941 - 1944/45), which carried out repressions against the people of Latvia. During the Soviet occupation, the KGB bodies in Latvia operated under Moscow's full control, and one of the aims of repressions was to prevent the restoration of Latvia's independence. In the totalitarian regime of the USSR, security authorities acted as executive bodies that were largely politicized in view of their task of defending the indisputable role of the communist ideology.

A clear-marked political orientation of security institutions is not characteristic of democratic regimes. On the opposite, one of the features of a totalitarian regime is the direct reliance on strong secret police, which ensures unconditional submission of the population to the regime. ${ }^{2}$

On May 4, 1990, the Supreme Council of the Latvian Soviet Socialist Republic (LSSR) adopted the Declaration on the Restoration of the Independence of the Republic of Latvia, which, among other things, required the restoration of the Satversme (Constitution) of the Republic of Latvia adopted on February 15, 1922, throughout the whole country of Latvia. ${ }^{3}$ The Declaration of Independence of May 4, 1990, proclaimed a transitional period for regaining complete independence, as all financial, administrative, and military resources were still in the hands of Moscow. Latvia chose a gradual, non-violent resistance path that entered history as the "singing revolution." The transitional period was a period of turbulence, dramatic popular emotional upsurge, and political events, culminating in the constitutional law On the Statehood of the Republic of Latvia, adopted by the Supreme Council on August 21, 1991, which envisaged a complete restoration of the independence of Latvia. ${ }^{4}$ Restoration of independence also meant the re-establishment of democracy, which was partially lost already in 1934 in the course of the authoritarian coup by Kārlis Ulmanis and completely lost in 1940 with the Soviet occupation.

1 History of Security Police, http://www.dp.gov.Iv/lv/vispariga-informacija/vesture/, accessed March 17, 2018.

2 Ritvars Jansons, “Activities of the Security Services of the Latvian SSR (1944 - 1956)," in VDK zinātniskās izpētes komisijas raksti, ed. K. Jarinovska (Rīga: LPSR VDK zinātniskās izpētes komisija, LU Latvijas vēstures institūts, 2016), 97-115, accessed March 11, 2019, https://www.lu.lv/fileadmin/user_upload/lu_portal/projekti/vdkkomisija/ VDKkomisija_raksti_2sejums_LPSR-drosibas-iestazu-darbiba-1944-1956_2016-0506maijs_12-00.pdf. - in Latvian.

3 Declaration of the Supreme Soviet of the Latvian SSR "On the Renewal of the Independence of the Republic of Latvia," accessed March 14, 2019, available at https://likumi.lv/doc.php?id=75539\&mode=DOC. - in Latvian.

4 "Law on the Statehood of the Republic of Latvia," Likumi.lv, August 21, 1991, accessed March 11, 2019, https://likumi.Iv/doc.php?id=69512. 
Since 1990, Latvia has achieved a lot. The Soviet regime had eliminated almost all the spheres of economic and public activities in Latvia. Many sectors had to start almost from scratch. Public administration, economy, agriculture, and foreign trade, which until then were performed mostly by other republics of the USSR, underwent radical changes. Privatization, economic and political reforms allowed relatively quickly to shift to the Western development practice, from which Latvia was forcibly withdrawn for 50 years.

Nowadays, Latvia is a democratic country and member of the European Union, NATO, and the Organization for Economic Co-operation and Development (OECD), as well as a member of the Schengen and Eurozone. In the ranking of Freedom House's Nations in Transit in 2018, Latvia is rated as a consolidated democracy; its achievements among the 29 countries of transit to liberal democracy are surpassed only by Estonia. ${ }^{5}$

Latvia is followed in this ranking by Slovenia, the Czech Republic, and Lithuania. ${ }^{6}$ Remarkably, Latvia ranks as the first (together with Estonia) in the chapter Democratic Governance, leaving behind all remaining post-soviet countries. ${ }^{7}$ The achievements in this area are important because they have also ensured democratic principles in the civilian control over the Latvian security services.

\section{The Structure of the State Security Services of Latvia in 1990-1991}

Although on May 4, 1990, the Supreme Council of the LSSR announced a transition period for the restoration of independence, the Committee for State Security of the LSSR continued to operate on the territory of Latvia. The KGB of the LSSR was an influential and branched organization comprising the KGB leadership of the LSSR, administrative and operational units dealing with intelligence and counter-intelligence. There were specialized counter-intelligence units, operational activity departments (surveillance, operational technical unit, encryption, communications, etc.), and an investigative segment. The total number of officers in the KGB of LSSR was about 360-400 people. ${ }^{8}$ Each operative officer had around 10 to 20 agents. The largest number of employees served in the support unit of the operational activities, as well as in the management. The KGB of LSSR was a territorial unit of the KGB of the USSR and subordinated to its central leadership. Decrees about the main directions of work, recruitment, and retirement were signed by the Chairman of the KGB of the USSR. The KGB of the LSSR

5 Freedom House, “Nations in Transit 2018," p. 23., accessed March 17, 2019, https://freedomhouse.org/sites/default/files/FH_NationsInTransit_Web_PDF_FINAL _2018_03_16.pdf.

6 Freedom House, "Nations in Transit 2018."

7 Freedom House, "Nations in Transit 2018."

8 Indulis Zālīte, "Structure and Main Directions of Action of the State Security Committee of the Latvian Soviet Socialist Republic in 1980-1991," LPRA, accessed March 11, 2019, http://Ipra.vip.Iv/vdk_uzbuve.htm\#Structure. - in Latvian. 
was led by the Chairman of the KGB of the LSSR and his deputies, the Collegium of the KGB of the LSSR, and the Committee of the Communist Party. ${ }^{9}$

The Intelligence Unit (1st unit) contained: Section No.1, executing illegal intelligence activities; Section No.2, carrying out external counter-intelligence activities; Section No.3, scientific and technological intelligence; while Section No.4 carried out political intelligence. The last section in the list was created in the 1980s on the basis of Section No. 2 and was engaged in the screening of the agents of influence and recruitment of foreign nationals in order to influence socio-political processes. The Counter-Intelligence Unit (2nd unit) performed counter-intelligence tasks to protect the USSR against the activities of foreign special services. The unit's operation took place mainly in the USSR territory, although it had its own network of agents abroad. About 50-60 operational employees worked in this unit in 1990-1991. ${ }^{10}$

The 3rd unit of the intelligence branch of the Latvian KGB - the Support Unit of Counter-Intelligence by Law Enforcement Bodies was established in the early 1980s, dealing mainly with corruption and bribery issues in the system of internal affairs of the LSSR. By the end of the 1980s, its focus was on organized crime. In 1991, a new unit of the fight against organized crime was created on this basis. Unit No.4 - the Support Unit of the Transport Counter-Intelligence was created in 1982. Unit No.5 - Combat Against Ideological Sabotage was established in 1967 when ideological counter-intelligence was declared one of the KGB priorities. About 50-60 employees worked in this unit in 1990. By 1990, the KGB of the LSSR continued to operate units engaged in economic counter-intelligence, surveillance, investigation, radio remote sensing, etc. ${ }^{11}$

Preserving and reorganizing the KGB in Latvia after regaining independence in 1991 was not an option because it was created by a regime hostile to Latvia. The only rational choice was the liquidation of the KGB. On August 24, 1991, the Supreme Council of the Republic of Latvia passed a resolution "On Terminating the Activities of the USSR State Security Institutions in the Republic of Latvia." 12 According to the resolution, the activities of the KGB of the USSR and the LSSR in the territory of Latvia were prohibited. After restoring its independence in 1991, Latvia started building a new security system. This also included the establishment of a system of intelligence and counter-intelligence services.

One year earlier, on November 26, 1990, the Ministry of Interior of Latvia issued Order No. 200 to establish the 1st Police Battalion. This battalion can be considered the beginning of forming security and defense services of Latvia during the process of restoring independence. It is noteworthy that the 1st Police Battalion carried out the task given by the Supreme Council to take over the KGB

9 Zālīte, "Structure and Main Directions of Action of the State Security Committee."

10 Zālīte, "Structure and Main Directions of Action of the State Security Committee."

11 Zālīte, "Structure and Main Directions of Action of the State Security Committee."

12 "Par PSRS valsts drošības iestāžu darbības izbeigšanu Latvijas Republikā," accessed March 11, 2019, http://www.barikadopedija.lv/raksti/375072. 
sites on August 24, 1991. The archives of the Committee for State Security were also taken over with the participation of the 1st Police Battalion. ${ }^{13}$ This battalion served as a basis for establishing the Security Service under the Supreme Council of Latvia that was later transformed into two different services - Security Service of the Republic of Latvia and the Dignitaries Protection Service.

On January 28, 1992, the Supreme Council of the Republic of Latvia passed a resolution "On the Renaming of the Security Service of the Supreme Council of the Republic of Latvia as the Security Service of the Republic of Latvia." ${ }^{14}$ According to the newly created staff regulations, the Security Service of the Republic of Latvia was a state institution directly subordinated to the Supreme Council of the Republic of Latvia, whose task was to protect the state power and economic interests of the Republic of Latvia. Compared to the Security Service of the Supreme Council, the structure of the Security Service of the Republic of Latvia changed according to its main tasks, and the number of staff increased slightly (882 posts were planned). ${ }^{15}$ Such changes were based on a significant increase in the level of official duties, as new embassies and missions were opened in the Republic of Latvia, foreign ambassadors were accredited, and the number of official delegations from other countries increased, all this increasing the number of facilities to be secured. Upon obtaining the new status, a working group was set up to develop a package of draft documents regulating the institution's main units, its legal basis, the forms, and structure of its activities. On June 4, 1992, the Presidium of the Supreme Council of the Republic of Latvia passed a resolution "On Approval of the Regulations of the Security Service of the Republic of Latvia." ${ }^{16}$ According to the regulations, the Security Service of the Republic of Latvia was directly subordinated to the legislative power of Latvia and acted in accordance with national laws. ${ }^{17}$ Thus, one can conclude that the institution was established first and, while already operating, all its legal and management aspects were further fine-tuned. Such a procedure was due to the atmosphere of uncertainty and urgency of that time; the need to avoid a power vacuum, especially considering the level of crime at that time and the presence of troops of

13 Raimonds Rublovskis, "Uzruna 20 gadu jubilejā. No 1. policijas bataljona līdz Latvijas Republikas Drošības dienestam un Militārajai policijai (1990-2013) [Address on the 20th Anniversary. From the 1st Police Battalion to the Security Service of the Republic of Latvia and the Military Police (1990-2013)]," accessed March 11, 2019, http://bataljons.Iv/index.php/raksti/31-raimonds-rublovskis-uzruna-1-policijasbataljona-20-gadu-jubileja.html.

14 "Lēmums Par Latvijas Republikas Augstākās Padomes apsardzes dienesta pārdēvēšanu," January 28, 1992, https://m.likumi.Iv/doc.php?id=72447, accessed March 17, 2019.

15 Rublovskis, "Uzruna 20 gadu jubilejā. No 1. policijas bataljona."

16 Likums Par Latvijas Republikas Drošības dienesta nolikuma apstiprināšanu, Likumi.lv, June 4, 1992, accessed March 17, 2019, https://likumi.lv/ta/id/66472-par-latvijasrepublikas-drosibas-dienesta-nolikuma-apstiprinasanu.

17 Rublovskis, "Uzruna 20 gadu jubilejā. No 1. policijas bataljona." 
the USSR (later, of the Russian Federation) in Latvia until 1994 (for some specific units until 1998).

In parallel, on November 4, 1991, the Council of Ministers issued Order No. 301 to establish the Information Department of the Ministry of Interior, entrusting intelligence and counter-intelligence functions to this security body. The Information Department consisted of four divisions:

1. Division for protection of the sovereignty of the Republic, with its regional sections;

2. International relations division, responsible for maintaining communication with foreign intelligence and counter-intelligence services;

3. Division of information analysis and development of recommendations, responsible for the analysis of operational information, as wells as preparing information on security matters for state officials;

4. A secretariat, responsible for managing documentation within the department.

The period from 1990 to 1993 demanded great commitment and determination from Latvian politicians and security personnel, as democratic reforms had to be implemented quickly, relying on the personal experience of the people involved and the increasing assistance from the Western allies.

\section{The Structure of the State Security Services of Latvia at the End of the Transformation Process}

Reforms continued after 1993 in the branch of institutions that sprouted from the 1st Police Battalion. On November 22, 1994, the Security Service of the Republic of Latvia was transformed into Security Service of the President of Latvia and Security Service of the Saeima (Parliament of Latvia). The next reorganization took place on July 1, 1997, when two separate units-the Security Service of the Saeima and the President of the State and the Military Police of the National Armed Forces (NAF) of the Republic of Latvia-were created on the basis of the President of the Republic of Latvia and the Saeima Security Service. The changes continued, and in 2010, the Security Service of the Saeima and the President of the State was incorporated in the Military Police of the NAF. As a result of the merger, the name of the Security Service was legally erased. In the summer of 2010, the NAF Military Police transferred a significant part of its functions to the State Police and the Security Police as a result of the reorganization. ${ }^{18}$ The functions initially performed by the 1st Police Battalion have now been partially taken over by the Military Police. This branch of security services has gradually transferred counter-intelligence and operational functions to other security ser-

18 "The History of the First Police Battalion," http://bataljons.Iv/index.php/vesture.html, accessed March 11, 2019. - in Latvian. 
vices while maintaining responsibility for the safety of persons, objects, and institutions within certain spheres.

A branch launched in 1991 with the establishment of the Information Department of the Ministry of Interior, continued further its institutional development. This service and the Dignitary Protection Service were merged in 1993, resulting in the establishment of the National Economic Sovereignty Protection Department (VESAD) ${ }^{19}$ with the aim to provide the security measures crucial at that time. The main functions of this security body were intelligence, counter-intelligence, and counterterrorism, as well as the fight against groups of organized crime. Initially, VESAD was created as a temporary solution to address topical issues of national security. Since rather a range of functions was entrusted to VESAD, it was a relatively ineffective security body. Therefore, in 1994 the recently established security system of Latvia was reorganized. In 1994, the Law on State Security Institutions ${ }^{20}$ was adopted, which stipulated the body and legal status of security and intelligence services in Latvia. At that point, VESAD was reorganized, and the Latvian Security Police was established.

The adoption of the 1994 Law on the State Security Institutions can be regarded as the end of the first phase of the establishment of the Latvian security system after regaining independence. This Law marked the modern security system in Latvia, with three security services operating in Latvia: Security Police (DP), ${ }^{21}$ Defense Intelligence and Security Service (MDID), ${ }^{22}$ and the Constitution Protection Bureau (SAB). ${ }^{23}$ With amendments to the Law on State Security Institutions, adopted in 2018, the Security Police has been renamed the Latvian State Security Service. ${ }^{24}$

\section{State Security Service}

During the first years after its establishment, the State Security Service (in that time - the Security Police) was responsible not only for counter-intelligence activities but also for carrying out intelligence gathering. However, in the year 2000 , the intelligence functions were transferred to the Constitution Protection Bureau (SAB). Furthermore, in 2003 the counter-espionage function was passed from DP to SAB. In 2004, to address current threats, a Counterterrorism Center was established within the structure of the Security Police. Thus, the State Security Service is the only security service in Latvia with responsibilities in this area as well.

\footnotetext{
19 In Latvian - Valsts Ekonomiskās suverenitātes aizsardzības dienests (VESAD).

20 "On State Security Institutions," Likumi.Iv, May 05, 1994, accessed March 17, 2019, https://likumi.lv/ta/en/id/57256-on-state-security-institutions.

21 In Latvian - Drošỉbas policija (DP).

22 In Latvian - Militārās izlūkošanas un drošības dienests (MIDD).

23 In Latvian - Satversmes aizsardzības birojs (SAB).

24 In Latvian - Valsts drošības dienests (VDD).
} 
The State Security Service is the Latvian counter-intelligence that gathers information, carries out its analysis, informs senior officials about identified threats to the national security, and takes measures to neutralize them. The State Security Service is responsible for conducting counter-intelligence activities, protecting constitutional order, protecting state secrets, economic security, coordinating and implementing counterterrorism measures, and protecting dignitaries. The State Security Service is also the only security service in Latvia with the right to carry out a pre-trial investigation (to initiate criminal proceedings, initiate criminal prosecution, and to arrest persons).

\section{Defense Intelligence and Security Service}

The Defense Intelligence and Security Service (MIDD) is one of the three state security institutions carrying out the tasks stipulated in the Law on State Security Institutions. MIDD is under the auspices of the Ministry of Defense. Its primary tasks include: protection of official secrets at the Ministry of Defense, its subordinate institutions and the National Armed Forces; intelligence and counter-intelligence in the military sphere; security vetting of employees of the Ministry of Defense for granting personnel security clearances for access to official secrets.

MIDD detects and prevents, in cooperation with other state security institutions, subversive activities carried out by foreign intelligence services, as well as activities against organizations and individuals within the Ministry of Defense, the institutions subordinated to it, and the National Armed Forces. MIDD checks candidates wanting to receive security clearances for conducting specific business activities subject to licensing and gives opinions on granting special security clearances. MIDD is acting as the national signals intelligence (SIGINT) authority of the Republic of Latvia. It carries out and controls SIGINT and guarantees the protection of the information collected. It carries out other tasks stipulated in the laws, regulations, and international treaties, ensuring inter alia efficient exchange of information with both NATO and European Union bodies and partner countries. ${ }^{25}$

\section{Constitution Protection Bureau}

The Constitution Protection Bureau (SAB) is a state security institution under the supervision of the Cabinet of Ministers. SAB was established in 1995 on the basis of the Law on the Constitution Protection Bureau adopted by the Saeima in 1994. ${ }^{26}$ The Constitution Protection Bureau's main tasks include intelligence, counter-intelligence, and protection of state (official) secrets. As the National Security Authority, SAB also ensures the protection of NATO and EU classified information in public institutions working with such information. SAB operates

25 "Defense Intelligence and Security Service (MIDD)," accessed March 17, 2019, https://www.midd.gov.Iv/en/about-us.

26 "Law of the Constitution Protection Bureau," May 19, 1994, accessed March 21, 2019, http://www.sab.gov.lv/?a=s\&id=33. 
in accordance with the National Security Law, the Law on State Security Institutions, the Law on the Constitution Protection Bureau of the Republic of Latvia, the Law on State Secrets, the Investigatory Operations Law, and the Cabinet of Ministers' regulations related to these laws. ${ }^{27}$

\section{Decisive Steps to Establish the State Security Services in Law and Practice}

Latvian security services were established after Latvia regained its independence through the implementation of several main measures. The transformation of the USSR institutions never happened because KGB was recognized as a criminal organization in Latvia and liquidated. Implementing a direct succession process with the security institutions that existed in Latvia prior to the Soviet occupation in 1940 was also challenging since they were dissolved long before. Therefore, one can speak not about t transformation but rather creation. Activities from 1990 to 1993 could be considered the first step in developing a renewed Latvian security system, which included both the creation of the 1st Police Battalion and the creation of the Information Department of the Ministry of the Interior. The creation of the 1st Police Battalion was important because it happened at a time when KGB was still working in Latvia. However, the branch of institutional development, originated by the creation of the Information Department of the Ministry of the Interior in 1991, after regaining complete independence, evolved further and laid the foundations first for VESAD, then for the establishment of the Security Police and later also for the Constitution Protection Bureau.

The establishment of the Security Police and the Constitution Protection Bureau (in 1994 and 1995, respectively) can be considered the conclusion of the foundation of the system of Latvian security institutions, cementing the modern security architecture in Latvia. This step, accompanied by a more significant rise in the financing of the security sector, was also important for the achievement of Latvia's foreign policy goals. In 1995, Latvia adopted the Main Directions of Foreign Policy until 2005 (as a Foreign Policy Concept), ${ }^{28}$ stipulating that Latvia's accession to NATO and the European Union was a foreign policy priority. Latvia's eventual NATO membership required confidence from the Western allies about the country's security system, which, among other things, should also be prepared to keep NATO military secrets. The security authorities had to be sure that their employees were loyal to the democratic and free development of Latvia and that the technical aspects of storing classified documentation should be arranged in accordance with NATO standards. In this regard, the State Security Service, the Constitution Protection Bureau, and the Military Security and Intelli-

27 The Constitution Protection Bureau (SAB), accessed March 17, 2019, www.sab.gov.Iv/ ?a=s\&id=1.

28 “Main Directions of Latvian Foreign Policy until 2005," December 2, 2014, accessed March 11, 2019, available at http://www.mfa.gov.Iv/arpolitika/latvijas-arpolitikaspamatvirzieni-lidz-2005-gadam. - in Latvian. 
gence Service did a fundamentally important work that brought Latvia closer to NATO in 2004.

The adoption in 1994 of the Law on State Security Institutions ${ }^{29}$ was the most important achievement in the legislative area; it defined the division of competences between the national security authorities and entities, the legal basis for action, objectives and tasks, duties and responsibilities, and regulated the financing, monitoring, and control of their activities. ${ }^{30}$ It is essential that the said law marks a fundamental difference from the Soviet regime, stating in Article 5 that "The activities of State security institutions shall be organized and carried out on a lawful basis, in conformity with the general human rights [..]." 31 The rule of law and respect for human rights are the principles that distinguish the activities of the Latvian services from the KGB activities during Soviet times. Since then, the Latvian legislation continued to evolve in response to new challenges; still, the changes were introduced on the basis put in place in 1994 by the Law on State Security Institutions.

\section{Internal and External Political Context, the Role of Individuals in Structuring the Reform Steps}

The first steps in establishing security services took place when the Supreme Council was still issuing laws in Latvia, the last of which was elected on March 18,1990 , with the Soviet Union shaking but still intact. In this election, the majority of the population supported the candidates nominated by the Latvian Popular Front (LTF), ${ }^{32}$ who supported the move towards Latvia's independence. Two factions emerged in the newly elected Supreme Council - the winning LTF with 131 members and the opposition Equity with 57 MPs. The LTF in 1990 stood for Latvia's full independence, whereas Equity was pro-Moscow-oriented. The number of MPs of the LTF was sufficient for the Supreme Council to decide in support of the Declaration of Independence on May 4, 1990, as well as to move forward with the security-related legislation.

In accordance with the Constitution adopted in 1922, the Republic of Latvia is a parliamentary state; therefore, the restoration of the Saeima (Parliament) activities in 1993 by the 5th Saeima elections was also logical. Eight parties overcame the four percent threshold with the best results for the party Latvian Way ("Latvijas celı̌s," 36 seats). Pro-Western parties created the ruling coalition: the Latvian Way, the Latvian Farmers' Union, and the Green Party. During its parliamentary term, the Saeima adopted important laws, including those related to defense and security. During its operation, Latvia became involved in the NATO Partnership for Peace program. The pro-democratic and West-oriented political

\footnotetext{
29 "On State Security Institutions," 1994.

30 "On State Security Institutions."

31 "On State Security Institutions."

32 In Latvian - Latvijas Tautas Fronte (LTF).
} 
elite of Latvia also ensured the development of appropriate legislation for the effectiveness and democratic control of security services. At the same time, it should be noted that the Western direction as a foreign policy priority was the reason for the activation of Russian security services in Latvia.

After regaining independence, the first parliamentary elections already showed the tendency, i.e., the fact that the Latvian voters and political parties they support can roughly be divided into pro-Western and pro-Moscow supporters. During the Soviet occupation period, Latvia has undergone substantial changes in the ethnic composition of the population. Before 1935, Russians living in Latvia composed 8.8 percent of the entire population, ${ }^{33}$ but by 1989 their share reached 34 percent. ${ }^{34}$ This change was not a natural process of migration, but an artificially implemented Moscow policy aimed at Sovietization, Russification, and national identity change. Latvian Communists who opposed such a USSR policy lost their jobs and often were deported from Latvia. Some of the Soviet-era Russian immigrants supported the efforts of Latvia's independence in the late 1980s, while another significant portion advocated preserving the USSR. An example of the active role of this public segment was the organization Interfront, which in 1989-1991 actively supported the preservation of the USSR and opposed the restoration of Latvia's independence. In addition, Interfront was also used by Russia's (USSR) special services. However, it must be emphasized that Russians living in Latvia have never been a homogeneous group. After 1991, many former Russian citizens of the USSR living in Latvia gained citizenship and integrated into social and public life. However, another part retained a negative attitude towards the Latvian state, its institutions, and pro-Western development with the set foreign policy priorities.

It is also important to take into account the fact that after the regaining of independence in 1991, the armed forces of the USSR, later the Russian Federation still were dislocated in Latvia until 1994. During this time, the Russian troops, including the intelligence and counter-intelligence units of the army and their network of agents, were still active in Latvia. Hateful propaganda was spread against Latvia and the West, officials of independent Latvia were being provoked and discredited. Latvia's experience in this field can be of use for allied and partner countries today. At that time, Latvia did not have the sort of security guarantees now provided by NATO. During the negotiations on the withdrawal of the Soviet (later Russian) armed forces, the Latvian delegation subjected to Russia's pressure and agreed to leave in Latvia 22,320 Russian army retirees (pensioners). The notion 'pensioner' may be misleading here as it is necessary to consider the

33 "Fourth Population Census in Latvia in 1935," CSB, September 22, 2015, accessed March 17, 2019, www.csb.gov.Iv/en/dati/e-publikacijas/fourth-population-censuslatvia-1935-latvian-and-french-43290.html. - in Latvian and French.

34 "Results of the all-union Population and Housing Census 1989, Latvian SSR," CSB, September 22, 2015, http://www.csb.gov.lv/en/dati/e-publikacijas/results-all-unionpopulation-and-housing-census-1989-latvian-ssr-demographic-ind, accessed March 17, 2019. - in Latvian. 
early retirement age of the army officers. According to political expert Tâlavs Jundzis, the number of persons left behind along with the neighboring state's former servicemen was actually between 75 and 100 thousand, given that most officers in Latvia lived with their families. ${ }^{35}$ In comparison with other groups of the society, the Soviet army officers were especially faithful to the Soviet power, and their mood influenced the opinion of the Russian population and Russia's political atmosphere in general. Latvia suffered more in this regard than the neighboring countries Estonia and Lithuania, as the headquarters of the USSR Baltic Military District during the occupation period was located in the capital of Latvia, Riga.

Thus, the establishment of Latvian security services in the early 1990s and their work took place under specific conditions and atmosphere. In addition to the security challenges, it has yet to be considered that the period was characterized by an economic crisis and a high crime rate. For Russia, which had not lost its regional ambitions, the situation provided some advantages. The aforementioned background made it easier for the Russian security services to recruit agents in Latvia. Further, it complicated the discussion on allowing former KGB employees to work in an independent security service in Latvia.

\section{The Role of Individuals}

There was concern among Latvian politicians that ex-KGB officers can continue to cooperate with Russian colleagues. It should be noted that just after the restoration of independence, there was a lack of qualified security specialists in Latvia. One of the persons who supported the involvement of former KGB employees was the experienced officer of interior affairs Aloizs Vaznis, who became Minister of Interior of Latvia in 1990. In August 1991, A. Vaznis received from the Head of the Government of Latvia, Ivars Godmanis, the task of forming an intelligence service of the restored Latvian state. A. Vaznis stated the following in an interview with the newspaper: "When I became Minister of the Interior, the USSR KGB was still in operation. I quietly and calmly established contacts with several leading employees of the KGB. [..] At that time, I succeeded in compiling a list of the KGB employees who were supportive of independent Latvia and whose knowledge and experience should be used for the benefit of Latvia." ${ }^{36} \mathrm{~A}$. Vaznis stressed that they were highly professional technicians who did not have any political motives. The former interior minister continued: "But I did not succeed in persuading the members of the Supreme Council who chose the easiest

35 Tālavs Jundzis, “Krievijas karaspēka izvešana no Latvijas 1992-1994: diplomātiska uzvara vai politiska piekāpšanās?" LZA Vēstis 68, no. 3/4 (2014): 4-22, accessed March 17, 2019, http://ww3.Iza.Iv/LZA_VestisA/68_3-4/1_Talavs\%20Jundzis_Krievias\%20 karaspeka\%20izvesana.pdf.

36 Uldis Dreiblats and Ritums Rozenbergs, "Latvijas izlūkdienestam - 20," NRA, November 4, 2011, accessed March 17, 2019, http://nra.Iv/latvija/politika/59217-latvijasizlukdienestam-20.htm. 
way: to break everything that existed before and destroy it all. Despite this position, I managed to negotiate for a number of professionals to assist in creating a new service." ${ }^{37}$ However, one should object to the former Minister here, as among the staff members of the Information Department of the Ministry of the Interior, later the VESAD, there were not only former technical employees of the KGB but also intelligence specialists. One example was Andris Trautmanis, Information Officer at the Ministry of the Interior, who worked in Germany, Britain, etc., as a KGB intelligence officer. In 1991, due to the absence of experienced staff members, it was decided to allow the involvement of a limited number of former KGB staff for a temporary, transitional period, in order to transfer their experience to Latvia's new intelligence officers. In the following years, their knowledge was quickly complemented by the security services of NATO member states. Latvian services established good cooperation with the services of France, UK, Germany, the United States, and other countries.

Continuing to examine individuals who invested their efforts in establishing Latvian security services at the beginning of the 1990s, we can highlight the role of politicians and officials, as well as security personnel. Among the latter, one should mention Juris Vectirāns, who was in charge of the security of the Supreme Council and the Government of Latvia in 1990-1991. That was a stormy period when Latvia's independence was not yet carved in stone. General J. Vectirāns had graduated from the Minsk Higher School of the Ministry of the Interior during the Soviet era, and later, in an independent Latvia, he acquired additional knowledge at the G.C. Marshall European Center for Security Studies and at the Czech War Academy, as well as in the United States Government top-level courses. J. Vectirāns has served as the Chief of the Security Service of the President of the Republic of Latvia and the Saeima and as Head and General Inspector of the Riga Garrison of the National Armed Forces of Latvia.

Another important figure is Jānis Apelis, Head of the Information Department of the Ministry of the Interior, who replaced Yuriy Kuzin in this office. J. Apelis also led the Security Police from the end of 1996 to mid-1999. Jānis Apelis had extensive experience working in internal affairs structures; from 1986 to 1990, he worked in top positions of the Police office in Riga.

After transforming the Information Department of the Ministry of the Interior into the State Economic Sovereignty Protection Department (VESAD) in 1993, Raimonds Rožkalns was appointed as its head. He also led the Security Police from the summer of 1994 to the end of 1996 and was later the Deputy Director of the Constitution Protection Bureau. After his work in security services, Rožkalns became also known as the Latvian representative to NATO, and then as the security adviser to President Valdis Zatlers. Before his appointment in the security services, R. Rožkalns gained experience as a staff member of the internal affairs (Police) branch.

37 Dreiblats and Rozenbergs, "Latvijas izlūkdienestam - 20." 
In summary, the stories of the top official managers in the branch at the time were similar to an extent; namely, several of them have been employees of internal affairs, army or security institutions during the Soviet period, and after the fall of the Iron Curtain, they have gained additional knowledge in the West, as well as from cooperation with allied partner services in Latvia. Another feature emerged later with Latvia's continued integration with Western institutions professionals from security institutions who have no connection with the Soviet era came to the forefront. One such example is the former British Army General of Latvian origin Jānis Kažocinš, who became the Director of the Constitution Protection Bureau in 2003. Other former exile Latvians also provided assistance to the Latvian intelligence community, including Gunārs Meierovics, ${ }^{38}$ Olǵgerts Pavlovskis, ${ }^{39}$ and Valdis Pavlovskis. ${ }^{40}$ Former Latvian intelligence officers have expressed the opinion in interviews ${ }^{41}$ that the significance of the security services and information provided by them was most appreciated by the members of government Ivars Godmanis,, ${ }^{42}$ Māris Gailis,, ${ }^{43}$ Ziedonis Čevers, ${ }^{44}$ and others. This list of policymakers and security service officials of the early 1990s is far from complete. This article names only a small part of those who have contributed to strengthening Latvia's security right after regaining independence. Many security professionals remain behind the scenes, and they have done their job without any particular publicity.

\section{Organization of Civilian Democratic Oversight over the State Security}

\section{Services}

The current Latvian legislation defines the work of the security institutions with comprehensive, five-tier control and monitoring mechanism, which includes parliamentary control, supervision by the Cabinet of Ministers, judicial control, supervision by the Prosecutor's General Office, and financial control.

The Law on State Security Institutions, adopted in 1994, established, inter alia, democratic oversight over Latvian security institutions. Article 25 of the Law states that the Saeima and its National Security Committee shall exercise parliamentary control over the activities of national security authorities. The National Security Committee of the Saeima has the right to hear reports and surveys from the heads of national security authorities, as well as to read the documents and information of these authorities, except for documents on secret sources of this

38 Gunārs Meierovics, former employee of the US Department of Defense, former Head of the World Federation of Free Latvians, Latvian politician.

39 Olgerts Pavlovskis, Latvian politician and diplomat.

40 Valdis Pavlovskis, Minister of Defense of Latvia, 1993-1994.

41 Dreiblats and Rozenbergs, "Latvijas izlūkdienestam - 20."

42 Ivars Godmanis was the first Prime Minister of restored Republic of Latvia, 1990-1993.

43 Māris Gailis, Prime Minister of Latvia 1994-1995.

44 Ziedonis Čevers, Minister of Interior of Latvia, 1991-1993, 1997-1998. 
information. ${ }^{45}$ Thus, parliamentary control takes place both by listening to the special services reports and reviewing their work and, if necessary, by examining the documents from the security authorities to evaluate their work.

As for the executive's role, the Law states that the Cabinet of Ministers, within the limits of its competence, controls the activities of state security institutions. The Minister in charge carries out supervision over the subordinate national security authority in all areas, except for the state security authorities' operational activities, intelligence, counter-intelligence processes, and the official secret protection system. ${ }^{46}$ The differences between the three security services of Latvia are rooted in the fact that each of them is controlled by a different minister. The State Security Service is monitored by the Minister of Interior, the Constitution Protection Bureau is supervised by the Minister of Justice, while the Defense Intelligence and Security Service is under the oversight of the Minister of Defense.

The third pillar of the checks and balances system - the judiciary-has its role in supervising security services. All three national security authorities are subject to a unified judicial control mechanism over the special operational measures. The necessity and reasonableness of the special operational measures are assessed by the Chief Justice of the Supreme Court or his specially authorized judges of the Supreme Court. Only those special measures of operational activities, whose validity and compliance with the Law have been recognized by the Supreme Court judge, and the judge has sanctioned them, are carried out.

Article 26 of the Law on State Security Institutions states that the Prosecutor General and his specially authorized prosecutors supervise the operational activities, intelligence and counter-intelligence of state security institutions, and the official secret protection system. In carrying out the supervision, they are entitled to familiarize themselves with the documents, materials, and information held by the state security authorities. The identity of sources of information can only be discovered when they are directly involved in a crime, and only to the Prosecutor General; other authorized prosecutors can be informed only with the permission of the head of the national safety authority. ${ }^{47}$ For example, prosecutors of the Special Prosecution Division of the Prosecutor General Office arrive at the Constitutional Protection Office at least once a month to check the correspondence of the numbers entered in the Office's telephone conversation control system with the orders issued by the Supreme Court judges. ${ }^{48}$

The legality and reasonableness of the use of public funds allocated to the security services are checked by the State Audit Office every year on the basis of

\footnotetext{
45 "On State Security Institutions," Likumi.Iv, May 05, 1994.

46 "On State Security Institutions," Likumi.Iv, May 05, 1994.

47 “On State Security Institutions," Likumi.Iv, May 05, 1994.

48 "Supervision and control," The Constitution Protection Bureau, accessed March 19, 2019, http://www.sab.gov.lv/?a=s\&id=30. - in Latvian.
} 
the State Audit Office Law, ${ }^{49}$ while the compliance of the use of operational funds with the Law is verified by the State Auditor personally. ${ }^{50}$ The activities of security services are regulated also by the National Security Law, ${ }^{51}$ the Law on State Secrets, ${ }^{52}$ the Investigatory Operations Law, ${ }^{53}$ and the regulations of the Cabinet of Ministers related to these laws. The Constitution Protection Bureau's operation is regulated by another law - the Law on the Constitution Protection Bureau. ${ }^{54}$

The Latvian legislative base provides for proper democratic control over the activities of the security services. However, there have been some attempts by political forces and individuals to gain an unacceptably strong authority over security institutions. One such case occurred in 2007 when the Latvian government drafted amendments to the Law on State Security Institutions as well as to the National Security Law. However, since there were suspicions that these amendments were prepared in the interests of three Latvian so-called oligarchs Ainārs Šlesers, ${ }^{55}$ Aivars Lembers, ${ }^{56}$ and Andris Škēele, ${ }^{57}$ they were stopped from coming into force by the then President of Latvia Vaira Vike-Freiberga. Also, after the President refused to sign the amendments into force, a referendum was called. It took place on July 7,2007 . Although the referendum failed to reach the quorum of 453730 votes, the results showed massive disapproval of the amendments. ${ }^{58}$ Only 3 percent of voters supported the amendments, while 96 percent were against them. These amendments did not come into force. There were worries that if the amendments take place, the security services legislation would then allow too many parliamentarians and their officials to access state secrets. NATO also voiced concerns in regard to these amendments.

This case has shown that, while democracy is consolidating in Latvia, society must ensure that certain economic and political groups do not seize control over

49 "Law on State Control," Likumi.Iv, May 29, 2002, accessed March 10, 2019, https://likumi.Iv/doc.php?id=62538. - in Latvian.

50 "Supervision and control," The Constitution Protection Bureau.

51 "National Security Law," Likumi.Iv, December 29, 2000, accessed March 17, 2019, https://likumi.Iv/ta/en/id/14011-national-security-law. - in Latvian.

52 "Law on Official Secrets," Likumi.Iv, October 29, 1996, accessed March 19, 2019, https://likumi.lv/ta/en/id/41058-on-official-secrets.

53 "Investigatory Operations Law," Likumi.Iv, December 30, 1993, accessed March 20, 2019, https://likumi.Iv/doc.php?id=57573. - in Latvian.

54 "Law of the Constitution Protection Bureau," May 19, 1994.

55 Ainārs Slešers, Latvian businessman and politician who was Deputy Prime Minister of Latvia in $2002-2004$.

56 Aivars Lembergs, Latvian businessman and politician, mayor of Ventspils since 1988.

57 Andris Šḳēle, Latvian businessman and politician. He was Prime Mister of Latvia in 1995 - 1997 and 1999 - 2000. He is founder of Latvian People's Party.

58 "Referendum results," CVK, July 7, 2007, accessed March 16, 2018, www.cvk.Iv/ cvkserv/TN_2007/rez/index.html. 
special services. The second reminder is that, although the Soviet Union collapsed already in 1991, a part of the population of Latvia and even politicians still preserve pro-Moscow sentiments. The authoritarian regime and lack of democratic control over Russia's security services are not examples to follow because Latvia chose to strengthen the rule of law as one of its core values.

\section{Day-to-Day Work and Challenges for Latvian Security Services}

Although Latvian security services are working to prevent any illegal activity against Latvia from abroad, it is not a secret that the focus is on Russia's destructive actions. The Security Police Activity Report for 2017 states that "Russia's special services created the most important counter-intelligence risks to Latvia's national security." 59 The Russian-Georgian war in 2008 and the Russian aggression against Ukraine since 2014 have caused anxiety in countries neighboring Russia, including Latvia. Part of Russia's hybrid instruments in Ukraine are also employed against Latvia and other Baltic states. The work of the Latvian security services since 1991 has made it possible to conclude that harm to national security and functioning of democracy is caused not only by foreign espionage activity but also by hostile influence in a broad sense, which is illustrated in the last few years particularly by the proliferation of Russian disinformation and propaganda in Latvia. This problem has a complex nature and can be solved with the involvement of both state institutions and civil society organizations. In this context, the task of security services is to keep track of the various disruptive effects of foreign countries and inform the responsible public officials, politicians, and the general public to the extent possible, without compromising the state secrets.

Officials and politicians are kept informed by Latvian security services in closed sessions, while one of the ways to inform the wider public is the annual public reporting on the work of the services and threats to national security. For example, the State Security Service describes in its annual reports not only the activities of foreign intelligence but also the risks posed by Russia's compatriots' policy and Moscow-controlled media. Such activity reports make the wider public aware of the methods used by Russia against Latvia to impede the functioning of its democracy and create security risks.

In addition, Latvian security services carry out their daily work in the classical areas of intelligence, counter-intelligence, and counterterrorism. One of the main fields of Security Police work is counter-intelligence. The main task of counter-intelligence is to identify and prevent the activities of foreign intelligence services against the sovereignty of the Republic of Latvia, its economic, scientific, technical, and military potential, as well as national security and other vital in-

59 "Security Police Activity Report for 2017," Valsts drošības dienests (VDD), p. 12, accessed March 19, 2019, http://vdd.gov.lv/lv/?rt=documents\&ac=download\&id=32. in Latvian. 
terests of our country. ${ }^{60}$ Pre-emptive identification of terrorism threats and their prevention is a key responsibility of the Latvian State Security Service. During identification and neutralization of terrorist threats, the State Security Service closely cooperates with foreign partner services by regularly exchanging information. Along with conducting operational activities, assessing terrorist threats, and implementing preventive measures, the State Security Service also coordinates the activities of governmental and municipal institutions, as well as private sector companies involved in counterterrorism. ${ }^{61}$ The State Security Service regularly assesses the level of the terrorist threat that can be declared on the country's entire territory, the affected region, economic sector, or object. The level of the terrorist threat, based on the recommendation of the Head of the State Security Service, is declared by the Minister of the Interior.

The State Security Service and SAB are entrusted with issuing security clearances to those national or municipal authorities whose responsibilities stipulate access to state secrets. The State Security Service issues the second and third category security clearances for work with state secrets, which correspond respectively to classification levels secret and confidential. SAB issues security clearances of the first category - top secret. This area has been the subject of public and media debates in recent years, as officials and also parliamentarians who have been refused clearances have been publicly criticizing the Latvian security services. Every person who has been refused the post related to state secrets has the right to appeal this decision. ${ }^{62}$ The judgment to decline the security clearance can be appealed to the SAB Director within ten days, starting from the day the person has been informed about the judgment. The judgment made by the SAB director can, in turn, be appealed to the Prosecutor General within ten days, from the day the person was informed about the judgment. The judgment made by the Prosecutor General is final and cannot be appealed. ${ }^{63}$

Each of the security services in Latvia specializes in one of the security areas. The State Security Service, in addition to counter-intelligence and protection of the official secrets, continues to deal with threats of terrorism and the protection of dignitaries (it protects national and foreign dignitaries as well as dignitaries of international organizations visiting the Republic of Latvia). MIDD, on its part, focuses on defense and military threats, which have gained momentum after the illegal annexation of Crimea in 2014. SAB deals with counter-intelligence and intelligence, paying attention to cooperation with special services in other countries. The exchange of information with the services of other countries enables

60 "Counterintelligence," Latvian State Security Service, accessed March 9, 2019, https://vdd.gov.lv/en/areas-of-activity/counterintelligence/.

61 "Counterterrorism," Latvian State Security Service, accessed March 17, 2019, https://vdd.gov.Iv/en/areas-of-activity/counterterrorism/.

62 "Protection of State Secrets," Latvian State Security Service, accessed March 17, 2019, http://vdd.gov.Iv/en/areas-of-activity/protection-of-state-secrets/.

63 "Protection of State Secrets." 
faster and more accurate identification of a potential threat by foreign special services and its prevention. In the framework of NATO, the SAB conducts extensive cooperation in the field of intelligence and counter-intelligence. In the institutional framework of the EU, SAB cooperates with the EU Intelligence Centre (EU INTCEN), participates in several EU security committees, and conducts practical counter-intelligence work with the security services of EU institutions. Beyond the international institutional formats, SAB has developed active cooperation with foreign special services over a long time. Bilateral relations are also an essential form of cooperation. ${ }^{64}$

Compared to the beginning of the 1990s, Latvian security services are in a politically more stable situation. The amount of financing provided has increased significantly due to the growth of Latvia's economy. The legislation provides a clear institutional framework for the functioning of services in a democratic environment. In addition, security staff have accumulated experience over the years and have established an active cooperative practice with the partner services of NATO member states.

\section{Conclusion}

The establishment of Latvian security services was not a one-day or even oneyear enterprise. It took time and effort. In the early 1990s, the country's limited financial potential had a significant impact on these processes. During the period of Soviet occupation, Latvia's economy was based on the ineffective socialist planning economy, and hence the very low starting position in 1991. It was possible to develop the functions and capacity of the security services only within that financial framework. However, the process of setting up Latvian security services suggests that the most important precondition for quick reforms is not so much the level of financing but rather the confidence, values, and decisiveness of the officials and security officers.

The transformation of the system of security services took place in several steps and almost ten years (starting from 1990). During this period, different security institutions were responsible for different tasks that were most urgent at that time. This transformation process can be appraised as a "piecemeal" quasievolutionary way without any hard political fights fought during the establishment of Latvia's current security system. The adoption of the Law on State Security Institutions in 1994 can be considered the beginning in forming the system of Latvia's security services as it is known today. Therefore, the acceptance of this law can be considered as a decisive turning point in developing a security system that could fulfill its functions within a democratic society and under civilian oversight.

Also, expertise and knowledge shared by Western security services had a remarkable significance in shaping the system of security services in Latvia and un-

64 "International Cooperation," Constitution Protection Bureau (SAB), accessed March 29, 2019, http://www.sab.gov.Iv/?a=s\&id=29. - in Latvian. 
derstanding the role of such services in securing a democratic state. Therefore, the readiness of Western security services to come with advice and consultations can also be considered decisive in transforming the security services into fully capable security bodies that can guard state's secrets and neutralize possible threats to the security of Latvia.

Countries that are still in the process of democratic transition can learn from Latvia's example that it is crucial to act decisively and quickly when selecting loyal employees who are sufficiently motivated to serve in promoting national security. The second recommendation is to develop a legislative framework that is clear and in line with democratic principles. Third, democratic control of the services is of fundamental importance. It must be based on the checks and balances philosophy, which means that supervision and control are carried out along parliamentary, government, judicial, prosecution, and financing venues. The practical and uncompromising nature of such a system will ultimately increase public confidence in the security services. Without this confidence, consolidated democracy is unthinkable.

\section{Disclaimer}

The views expressed are solely those of the author and do not represent official views of the PfP Consortium of Defense Academies and Security Studies Institutes, participating organizations, or the Consortium's editors.

\section{Acknowledgment}

Connections: The Quarterly Journal, Vol. 18, 2019 is supported by the United States government.

\section{About the Author}

Andis Kudors is a Lecturer in the Department of Political Science, University of Latvia. He was Executive Director of the Centre for East European Policy Studies (2006-2019). Andis Kudors is a 1996 graduate of the International Law and Economics Program at the University of Latvia's Institute of International Affairs. From 2005 until 2011, he studied political science at the University of Latvia, specializing in Latvian-Russian relations and earning Bachelor and Masters of Art degrees in political science. His research interests include current foreign policy trends in Eastern Europe, Russian foreign policy, Russian compatriot policy, public diplomacy, propaganda, and disinformation. He is a member of the Foreign Policy Council at the Latvian Ministry of Foreign Affairs since 2011. Kudors is an author of many analytical articles about Russian foreign policy and Latvian security and editor of several books, including "Fortress Russia: Political, Economic, and Security Development in Russia Following the Annexation of Crimea and its Consequences for the Baltic States" (2016), "The War in Syria: Lessons for the West" (2016), "Belarusian Foreign Policy: 360" (2017). Andis Kudors had been Fulbright scholar at the Kennan Institute, Woodrow Wilson International Center for Scholars in Washington DC, USA (2014-2015). 